\title{
Enhancement of Hydrogen Production by Combining a Blend Ratio for Two Types of Algal Waste Biomass and Reducing Casamino Acids Supplementation By Clostridium butyricum RAK25832
}

\author{
Shahira Said Aly ${ }^{1,3}$, Tsuyoshi Imai ${ }^{2, *}$, Mohamed Salah Hassouna ${ }^{3}$, Takaya Higuchi ${ }^{2}$, \\ Ariyo Kanno $^{2}$, Koichi Yamamoto ${ }^{2}$, Rinji Akada ${ }^{2}$, Masahiko Sekine ${ }^{2}$ \\ ${ }^{1}$ Graduate School of Environmental Sciences and Engineering, Yamaguchi University, Yamaguchi, Japan. \\ ${ }^{2}$ Graduate School of Sciences and Technology for Innovation, Yamaguchi University, Yamaguchi, Japan. \\ ${ }^{3}$ Department of Environmental Studies, Institute of Graduate Studies and Research, Alexandria University, \\ Alexandria, Egypt.
}

*Corresponding Author: Tsuyoshi Imai, Graduate School of Sciences and Technology for Innovation, Yamaguchi University, Tokiwadai, Ube, Yamaguchi 755-8611, Japan.

\begin{abstract}
A previous study by the present authors identified nutrients necessary for hydrogen production, which was enhanced by using casamino acids (CAAs) as a nitrogen source. However, CAAs are costly; accordingly, using algal waste substrates with different nutrient compositions was speculated to serve as an alternative strategy for increasing hydrogen production from biomass. The present findings showed that optimizing the levels of the minerals $\mathrm{FeCl}_{2}, \mathrm{NaHCO}_{3}, \mathrm{MgCl}_{2}$, and $\mathrm{K}_{2} \mathrm{HPO}_{4}$ improved hydrogen yield (HY) to $107 \mathrm{ml} \mathrm{H}_{2}$ /volatile solids (VS). Using Chlorella fusca or Ulva lactuca as a single substrate, the cultures required CAAs supplementation at concentrations of 13.33 and $6.67 \mathrm{~g} / \mathrm{l}$, respectively. However, using a blend

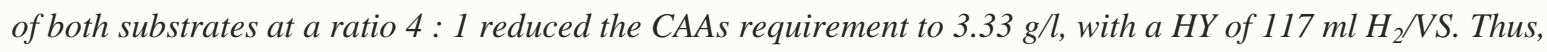
feedstocks consisting of biomass from different sources reduce the amount of CAAs required, therefore decreasing cost whilst increasing effective energy production.
\end{abstract}

Keywords: Casamino acids, Chlorella fusca, Ulva lactuca, Clostridium butyricum, Dark fermentation

Abbreviations

CAAs, casamino acid; FID, flame ionization detector; HPB, hydrogen-producing bacteria; HY, hydrogen yield; OD 620 , optical density at $620 \mathrm{~nm}$; TS, total solid; VFA, volatile fatty acids; VS, volatile solid

\section{INTRODUCTION}

Concerns regarding fossil fuel depletion and their environmental impact from burning- particularly greenhouse gas emissions - have prompted a search for alternative renewable energy sources (HahnHägerdal et al., 2006). Biofuel produced from biomass is an alternative to fossil fuels that has many benefits, including reduced environmental impact, greater energy security, and foreign exchange savings (Balat, 2010; Kan, 2009).

Dark fermentation has attracted increasing interest over the last decade for its potential to produce 'green' hydrogen from readily available and low-cost organic biomass (Azwar et al., 2014); a high rate and yield are important for the sustainability of commercial biohydrogen production. Fermentative hydrogen production by hydrogen-producing bacteria (HPB) requires trace amounts of essential metal ions (Wang \& Wan, 2009), although higher concentrations inhibit bacterial metabolism (Liu et al., 2009). In a previous stage of this work, it was shown that hydrogen production by Clostridium butyricum RAK25832 required four critical minerals, namely $\mathrm{MgCl}_{2} \cdot 6 \mathrm{H}_{2} \mathrm{O}$, $\mathrm{K}_{2} \mathrm{HPO}_{4} \cdot 3 \mathrm{H}_{2} \mathrm{O}, \mathrm{NaHCO}_{3}$, and $\mathrm{FeCl}_{2} \cdot 4 \mathrm{H}_{2} \mathrm{O}$, and that casamino acids (CAAs) are an important source of nitrogen for hydrogen production (Aly et al., 2017). CAAs are amino acids derived from casein acid hydrolysis and are used as a supplement in bacterial cultures to enhance growth. However, CAAs 
are expensive to scale up (Lev, 1977; Lindsay \& Murrell, 1983; Nolan, 1971), which is a major impediment to large-scale biohydrogen production. There is, therefore, a need to develop more economically feasible strategies (Cheng et al., 2011).

One way to lower the cost of biohydrogen production is to use low-cost and renewable feedstock. Aquatic biomass - especially macro- and micro-algae - have many advantages as biofuel substrates. Firstly, algae have higher productivity than agricultural crops and do not require arable land, and therefore do not compete with human food production (Dismukes et al., 2008; Fargione et al., 2008; Sialve et al., 2009). Secondly, their low lignin content facilitates the process of energy conversion from biomass to biofuels (Jones \& Mayfield, 2012; Wei et al., 2013). The use of residual biomass after lipid extraction can maximize energy production from micro-algal biomass (Brennan \& Owende, 2010). Chlorella fusca was shown to be a good feedstock for biodiesel production (lipid content 20.4\%) (unpublished data). Biofuels may be derived from oil (biodiesel) or sugar (e.g., biohydrogen and bioethanol) via sequential or independent processes (biorefinery concept).

Macro-algal blooms have many detrimental effects. Seaweed wrack accumulates along shorelines and produces foul odors (Wilce et al., 1982), while deep seaweeds physically obstruct other coastal life (Hauxwell et al., 2001); moreover, decaying algal organic matter creates anoxic conditions that kill fish and shellfish (Diaz, 2001). Ulva lactuca blooms are an environmental problem in the coastal areas of Japan, especially in the summer; in the Seto Inland Sea, blooms have replaced seagrasses (Sugimoto et al., 2007). Nonetheless, U. lactuca is a potential substrate for hydrogen production (Park et al., 2009).

This study aimed to investigate whether algal waste could be used to produce hydrogen at a low cost with high yield. Yield optimization by $\mathrm{MgCl}_{2} \cdot 6 \mathrm{H}_{2} \mathrm{O}, \mathrm{K}_{2} \mathrm{HPO}_{4} \cdot 3 \mathrm{H}_{2} \mathrm{O}, \mathrm{NaHCO}_{3}$, and $\mathrm{FeCl}_{2} \cdot 4 \mathrm{H}_{2} \mathrm{O}$ supplementation was investigated. Additionally, the applicability of biohydrogen produced by blending C. fusca with $U$. lactuca waste materials at various ratios to reduce the amount of CAAs required for dark fermentation by Clostridium butyricum RAK25832 was assessed.

\section{MATERIALS AND METHODS}

\subsection{Microorganism}

Fermentation was carried out using C. butyricum RAK25832 (Aly et al., 2017). The inoculum was cultured under anaerobic conditions in medium composed of glucose $(10 \mathrm{~g} / \mathrm{l})$, CAAs $(26.67 \mathrm{~g} / \mathrm{l})$, $\mathrm{MgCl}_{2} \cdot 6 \mathrm{H}_{2} \mathrm{O}(0.1 \mathrm{~g} / \mathrm{l}), \mathrm{K}_{2} \mathrm{HPO}_{4} \cdot 3 \mathrm{H}_{2} \mathrm{O}(6.67 \mathrm{~g} / \mathrm{l}), \mathrm{NaHCO}_{3}(2.6 \mathrm{~g} / \mathrm{l})$, and $\mathrm{FeCl}_{2} \cdot 4 \mathrm{H}_{2} \mathrm{O}(0.002 \mathrm{~g} / \mathrm{l})(\mathrm{pH}$ 8 ) at $30^{\circ} \mathrm{C}$, and was harvested at late exponential phase. The supernatant was transferred to anaerobic bottles that were sealed with a rubber and aluminum cap and then flushed with nitrogen gas. The initial inoculum was adjusted to a final optical density at $620 \mathrm{~nm}\left(\mathrm{OD}_{620}\right)$ of 0.1 by measuring the absorbance with a U-1800 spectrophotometer (Hitachi, Tokyo, Japan) (Pan et al., 2008). All chemicals were obtained from Wako Pure Chemical Industries (Osaka, Japan).

\subsection{Algal feedstock}

The micro-algal biomass $C$. fusca was obtained from the river Nile in Alexandria, Egypt and identified by Petrotech-ffn Egypt R \& D Center (Mansoura, Egypt). The isolate was grown in a 10-1 Magnaferm fermentor (New Brunswick Scientific Co., New Brunswick, NJ, USA) in commercial medium $(1 \mathrm{~g}$ urea and $0.3 \mathrm{~g}$ potassium phosphate $/ 10 \mathrm{l}, \mathrm{pH} 7)$ at $25^{\circ} \mathrm{C}$ and under a light intensity of 1,200 lux (540 Meter; Testo, Sparta, NJ, USA) measured at the surface of the photo-bioreactor, with aeration at a rate of $10 \mathrm{l} / \mathrm{min}$. For harvesting, the biomass was allowed to settle by gravity and then centrifuged at $4000 \mathrm{rpm}$ for $10 \mathrm{~min}$ (Beckman Model; TJ-6, USA) after removing most of the liquid phase. The wet biomass was oil extracted by the method of Bligh and Dyer (Bligh \& Dyer, 1959), yielding $510 \mathrm{mg} / \mathrm{l}$ dry weight biomass with a lipid content of $20.4 \%$. The algal pellet remaining after extraction was washed three times with clean water, dried overnight $(12 \mathrm{~h})$ at $70^{\circ} \mathrm{C}$, and stored at $-20^{\circ} \mathrm{C}$ until use as a substrate in the fermentation reaction. The macro-alga $U$. lactuca was harvested during the summer (May to July) at low tide on Wajiro beach, Fukuoka prefecture, Japan. The biomass was cleaned with tap water, dried at $70^{\circ} \mathrm{C}$, passed through a $200-\mu$ sieve, and stored at $-20^{\circ} \mathrm{C}$.

The chemical composition of algal biomass was determined, with measurements performed in duplicate (Table 1). Total solid (TS) and volatile solid (VS) in each type of algal biomass were 
determined according to Standard Methods 2540 G (APHA, 2005). Moisture content was determined by drying the sample in an oven at $105^{\circ} \mathrm{C}$ until it reached a constant weight. Total ash was determined by incineration at $550^{\circ} \mathrm{C}$ in a muffle furnace. The average moisture and ash contents were used to calculate VS content. Protein content was estimated with the Lowry protein assay (Berges et al., 1993), and total lipid content was determined according to Bligh and Dyer method (Bligh \& Dyer, 1959). Carbon, hydrogen, and nitrogen content was determined with a Micro Corder JM 10 element analyzer (J-Science Lab Co., Kyoto, Japan). Amino acid content was determined with an LC-500/V2 amino acid analyzer (Shimadzu, Kyoto, Japan) with lithium citrate (pH 2.98) as the buffer solution.

\subsection{Biohydrogen production}

Twelve sets of experiments were carried out to establish the optimal substrate blend ratio that would enhance hydrogen yield (HY). U. lactuca and C. fusca (6 g VS each) were mixed in a 225-ml serum bottle at various ratios. The working volume was adjusted to $100 \mathrm{ml}$ after adding $\mathrm{MgCl}_{2} \cdot 6 \mathrm{H}_{2} \mathrm{O}(0.1$ $\mathrm{g} / \mathrm{l}), \mathrm{K}_{2} \mathrm{HPO}_{4} \cdot 3 \mathrm{H}_{2} \mathrm{O}(6.67 \mathrm{~g} / \mathrm{l}), \mathrm{NaHCO}_{3}(2.6 \mathrm{~g} / \mathrm{l})$, and $\mathrm{FeCl}_{2} \cdot 4 \mathrm{H}_{2} \mathrm{O}(0.002 \mathrm{~g} / \mathrm{l})$. The 12 C. fusca: $U$. lactuca ratios by g VS were $6: 0,0: 6,3: 3,4: 2,4.5: 1.5,4$. 8: $1.2,5: 1,2: 4,1.5: 4.5,1.2: 4.8$, 1: 5 , and ( $3: 3$ ) (Table 2). Groups 1 and 2 (6:0 and $0: 6$ ratios, respectively) represented the controls for each feedstock, while group 12 ( $3: 3$ ratio) served as a control without mineral supplementation. The experiment was performed in triplicate and the results are expressed as average \pm standard deviation. Cultures were placed in a 120 -rpm shaking water bath at $30^{\circ} \mathrm{C}$ for $48 \mathrm{~h}$, with the initial pH adjusted to 8.00 with $1 \mathrm{M} \mathrm{NaOH}$ and $1 \mathrm{M} \mathrm{HCl}$, and were sterilized in an autoclave at $121^{\circ} \mathrm{C}$ for 15 min (2 atm) before starting the fermentative process. The initial inoculum was obtained at an $\mathrm{OD}_{620}$ of 0.1 in the final exponential phase. Bottles were sealed with rubber stoppers and purged with $\mathrm{N}_{2}$ to maintain anaerobic conditions.

Biogas volume was measured every $6 \mathrm{~h}$ by releasing the pressure in the bottle using wetted glass syringes (50-100 ml) (Owen et al., 1979). The composition of the liquid phase was determined at the end of the fermentation process. $\mathrm{HY}\left(\mathrm{ml} \mathrm{H}_{2} / \mathrm{g} \mathrm{VS}\right.$ alga) was calculated by dividing the total volume of hydrogen produced by the amount of algal biomass used as fermentation substrate in terms of its VS content.

The most favorable algal blend ratio obtained was optimized by including the following minerals to enhance final yield: $\mathrm{FeCl}_{2} \cdot 4 \mathrm{H}_{2} \mathrm{O}(0,0.001,0.002$, and $0.004 \mathrm{~g} / \mathrm{l}), \mathrm{NaHCO}_{3}(0,0.87,1.73,2.6$, and 3.47 $\mathrm{g} / \mathrm{l}), \mathrm{MgCl}_{2} \cdot 6 \mathrm{H}_{2} \mathrm{O}(0,0.1,0.2$, and $0.4 \mathrm{~g} / \mathrm{l})$, and $\mathrm{K}_{2} \mathrm{HPO}_{4} \cdot 3 \mathrm{H}_{2} \mathrm{O}(0,1.6,3.33$, and 6.67) $\mathrm{g} / \mathrm{l}$. The potential for reducing CAA supplementation (392-00655; Wako Chemical Industries) was evaluated by mixing algal waste at specific ratios with CAA $(3.33,6.66,13.33$, and $26.67 \mathrm{~g} / \mathrm{l})$.

\subsection{Analysis of chemical composition}

The biogas was collected directly from the headspace of the serum bottles using a gas-tight syringe. The gaseous phase was analyzed by gas chromatography (GC-8APT; Shimadzu) with a thermal conductivity detector and a Porapak Q stainless-steel column packed with an activated carbon 60/80 column $(1.5 \mathrm{~m} \times 3.0 \mathrm{~mm}$ internal diameter $)$. Argon was used as the carrier gas at a flow rate of 6.5 $\mathrm{ml} / \mathrm{min}$. Operation temperatures for the injector, column, and detector were $50^{\circ} \mathrm{C}, 60^{\circ} \mathrm{C}$, and $50^{\circ} \mathrm{C}$, respectively. Volatile fatty acid (VFA) concentration in the liquid phase was determined by gas chromatography with a flame ionization detector (FID) and 8-foot glass column packed with $10 \%$ polyethylene glycol-20M and $2 \% \mathrm{H}_{3} \mathrm{PO}_{4}(80 / 100$ mesh). The temperatures of the injection port, FID detector, and oven were $250^{\circ} \mathrm{C}, 140^{\circ} \mathrm{C}$, and $140^{\circ} \mathrm{C}$, respectively. Nitrogen was used as the carrier gas at a flow rate of $20 \mathrm{ml} / \mathrm{min}$. Ethanol concentration was determined by high-performance liquid chromatography (LC_10AD equipped with a Shim pack SPR-PB column; Shimadzu); the oven temperature was $80^{\circ} \mathrm{C}$, and deionized water was used as the mobile phase at a flow rate of $0.6 \mathrm{ml} / \mathrm{min}$ with a refraction index detector. Ammonia level was detected at the end of the fermentation process according to $4500-\mathrm{NH}_{3}$ standard methods (APHA, 2005).

\subsection{Kinetics of hydrogen production}

The amount of hydrogen gas produced was determined by measuring vial headspace gas composition and total biogas volume at each time interval according to the following mass equation:

$$
\mathrm{V}_{\mathrm{H}, \mathrm{i}}=\mathrm{V}_{\mathrm{H}, \mathrm{i}-1}+\mathrm{C}_{\mathrm{H}, \mathrm{i}}\left(\mathrm{V}_{\mathrm{G}, \mathrm{i}}-\mathrm{V}_{\mathrm{G}, \mathrm{i}-1}\right)+\mathrm{V}_{\mathrm{H}}\left(\mathrm{C}_{\mathrm{H}, \mathrm{i}}-\mathrm{C}_{\mathrm{H}, \mathrm{i}-1}\right)
$$


where $\mathrm{V}_{\mathrm{H}, \mathrm{i}}$ and $\mathrm{V}_{\mathrm{H}, \mathrm{i}-1}$ are the cumulative hydrogen gas volumes, $\mathrm{V}_{\mathrm{G}, \mathrm{i}}$ and $\mathrm{V}_{\mathrm{G}, \mathrm{i}-1}$ are the total biogas volumes, and $\mathrm{C}_{\mathrm{H}, \mathrm{i}}$ and $\mathrm{C}_{\mathrm{H}, \mathrm{i}-1}$ are the hydrogen gas fractions in the headspace at the current (i) and previous ( $\mathrm{i}-1$ ) time intervals, respectively; and $\mathrm{V}_{\mathrm{H}}$ is the total headspace volume of vials (Logan et al., 2002).

Cumulative volume of produced hydrogen was determined according to a modified Gompertz equation (Lay et al., 1997):

$$
\mathrm{H}=\mathrm{P} \exp \left\{-\exp \left[\frac{R_{m} \mathrm{e}}{\mathrm{P}}(\lambda-t)+1\right]\right\}
$$

where $\mathrm{H}$ is cumulative hydrogen production $(\mathrm{ml}) ; \lambda$ is lag time $(\mathrm{h}) ; \mathrm{P}$ is hydrogen production potential $(\mathrm{ml}) ; \mathrm{R}_{\mathrm{m}}$ is maximum hydrogen production rate $(\mathrm{ml} / \mathrm{h})$; and e is a constant $(2.718281828) . \mathrm{P}, \mathrm{R}_{\mathrm{m}}$, and $\lambda$ values for each batch were estimated using the solver function of SigmaPlot v.12 software (Systat Inc., San Jose, CA, USA) with a Newtonian algorithm.

\section{RESULTS AND DISCUSSION}

\subsection{Determination of $C$. fusca and $U$. lactuca ratio for optimal $H Y$}

Twelve co-fermentation groups with different blend ratios of $C$. fusca and $U$. lactuca waste biomass were evaluated to determine the ratio for maximal HY (Fig. 1). The duration of the fermentation reaction was $48 \mathrm{~h}$. HY was in the range of $22-90 \mathrm{ml} \mathrm{H} / \mathrm{g}$ VS. The highest yields were for groups 6 and 7; however, ammonia concentration was also higher for group 7 (Table 2). The control groups had low yield: for group 1, the yield was only $53 \mathrm{ml} \mathrm{H}_{2} / \mathrm{g} \mathrm{VS}$, likely due to an insufficient amount of free amino acids (nitrogen source) for hydrogen production by HPB. This is supported by a previous study reporting that high $\mathrm{C} / \mathrm{N}$ ratios in some algae led to VFA accumulation and depleted the nitrogen available for fermentative bacteria (Xia et al., 2016). The low ammonia concentration in group 1 also indicated that there was no surplus nitrogen in the form of free amino acids. The HY for group 2 was even lower $\left(22 \mathrm{ml} \mathrm{H}_{2} / \mathrm{g} \mathrm{VS}\right.$ ), whereas ammonia concentration was high (164 mg/l), reflecting an abundance of nitrogen in excess of bacterial needs. Low $\mathrm{C} / \mathrm{N}$ ratios in some algal species can lead to a high ammonia concentration, which inhibits fermentation (Allen et al., 2013). Accordingly, blending the two types of waste biomass increased HY, since nitrogen depletion by one type of waste could be compensated by the other. A comparison of groups 3 and 12 revealed that mineral supplementation is important for hydrogen production. Mineral depletion resulted in a delay in lag time by $50 \%$, leading to a lag time of $20 \mathrm{~h}$, and the overall yield decreased $20 \%\left(35 \mathrm{ml} \mathrm{H}_{2} / \mathrm{g} \mathrm{VS}\right)$. The main VFAs produced were acetic acid and butyric acid (Table 2), as expected for C. butyricum; this resulted in acidification of the culture. The $C$. fusca : U. lactuca ratio of group 6 (4: 1), which had an $\mathrm{HY}$ of $86 \mathrm{ml} \mathrm{H}_{2} / \mathrm{g} \mathrm{VS}$ and lag time of $2 \mathrm{~h}$, was selected for further experiments.

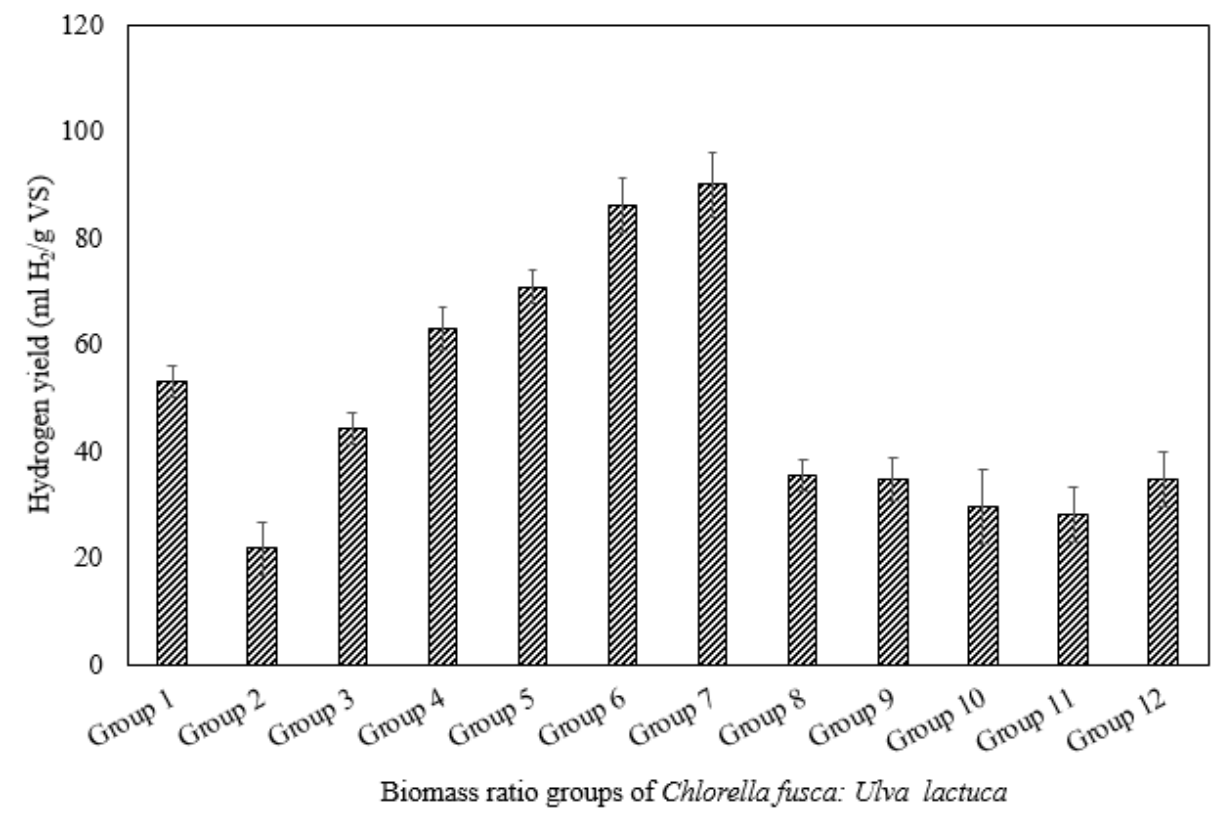

Figure 1. Effect of different C. fusca and U. lactuca biomass blend ratios on HY by C. butyricum RAK25832 
Enhancement of Hydrogen Production by Combining a Blend Ratio for Two Types of Algal Waste Biomass and Reducing Casamino Acids Supplementation By Clostridium butyricum RAK25832

Table 1. Characteristics of macro-algal biomass (U. lactuca) and micro-algae (C. fusca)

\begin{tabular}{|l|c|c|}
\hline & \multicolumn{2}{|c|}{ Algal biomass } \\
\hline & C. fusca & U. lactuca \\
\hline TS (wwt \%) & 93.34 & 95.44 \\
\hline VS (wwt \%) & 94.60 & 82.18 \\
\hline Moisture (wwt \%) & 6.66 & 4.56 \\
\hline Ash (fixed solids; \% TS) & 5.40 & 17.82 \\
\hline C (\%T) & 47.48 & 35.36 \\
\hline H (\%T) & 6.83 & 5.20 \\
\hline N (\%T) & 8.76 & 3.95 \\
\hline O (\%T) & 31.53 & 37.67 \\
\hline C/N ratio & 5.42 & 8.95 \\
\hline Proteins (\% VS) & 42.52 & 22.58 \\
\hline Lipids (\% VS) & 20.40 & 1.00 \\
\hline
\end{tabular}

TS, total solid; VS, volatile solid.

Table 2. Kinetics parameters of hydrogen production by Clostridium butyricum RAK25832 using different ratios of waste biomass micro-algae (C. fusca) and macro-algal biomass (U. lactuca)

\begin{tabular}{|c|c|c|c|c|c|c|c|c|c|c|c|c|}
\hline \multirow[b]{2}{*}{ Group } & \multirow[b]{2}{*}{$\begin{array}{c}\text { Biomass } \\
\text { blend } \\
\text { ratio }\end{array}$} & \multirow[b]{2}{*}{$\begin{array}{c}\text { Biomass } \\
\text { ratio } \\
\text { (C. fusca } \\
\text { : } U . \\
\text { lactuca) }\end{array}$} & \multirow[b]{2}{*}{$\begin{array}{c}\text { Final } \\
\text { pH }\end{array}$} & \multirow[b]{2}{*}{$\begin{array}{c}\mathrm{NH}_{4-}^{-} \\
\mathrm{N} \\
(\mathrm{mg} / \mathrm{l})\end{array}$} & \multicolumn{3}{|c|}{$\begin{array}{c}\text { Kinetics parameters } \\
\text { estimated from the } \\
\text { modified Gompertz model }\end{array}$} & \multicolumn{5}{|c|}{ VFA (mg-COD/l) } \\
\hline & & & & & $\begin{array}{l}\text { Hydrogen } \\
\text { rate } \\
\mathbf{R}_{\mathrm{m}}\end{array}$ & $\begin{array}{c}\lambda \\
\text { (h) }\end{array}$ & $\mathbf{R}^{2}$ & HAc & HPr & $\begin{array}{c}\text { I- } \\
\text { HBu }\end{array}$ & $\begin{array}{c}\text { N- } \\
\text { HBu }\end{array}$ & EtOH \\
\hline 1 & $1: 0$ & $6: 0$ & 4.51 & 8.00 & 15.8 & 15 & 0.9502 & 223 & 0 & 0 & 725 & 10 \\
\hline 2 & $0: 1$ & $0: 6$ & 4.33 & 164.67 & 6.4 & 6 & 0.9858 & 122 & 0 & 0 & 677 & 6 \\
\hline 3 & $1: 1$ & $3: 3$ & 4.23 & 134.06 & 20.00 & 10 & 0.9652 & 220 & 0 & 0 & 698 & 15 \\
\hline 4 & $2: 1$ & $4: 2$ & 4.33 & 159.16 & 22.08 & 9 & 0.9826 & 340 & 0 & 0 & 822 & 22 \\
\hline 5 & $3: 1$ & $4.5: 1.5$ & 4.33 & 74.07 & 20.27 & 2 & 0.9788 & 350 & 0 & 0 & 835 & 23 \\
\hline 6 & $4: 1$ & $4.8: 1.2$ & 4.25 & 19.00 & 37.19 & 2 & 0.9988 & 450 & 0 & 0 & 1135 & 25 \\
\hline 7 & $5: 1$ & $5: 1$ & 4.13 & 25.56 & 39.03 & 2 & 0.9455 & 460 & 0 & 0 & 1132 & 23 \\
\hline 8 & $1: 2$ & $2: 4$ & 4.22 & 120.59 & 9.04 & 3 & 0.9669 & 166 & 0 & 0 & 689 & 10 \\
\hline 9 & $1: 3$ & $1.5: 4.5$ & 4.25 & 132.10 & 8.27 & 3 & 0.9563 & 161 & 0 & 0 & 683 & 11 \\
\hline 10 & $1: 4$ & $1.2: 4.8$ & 4.25 & 135.28 & 7.35 & 2 & 0.9345 & 158 & 0 & 0 & 679 & 10 \\
\hline 11 & $1: 5$ & $1: 5$ & 4.32 & 140.80 & 6.95 & 1 & 0.9340 & 152 & 0 & 0 & 677 & 8 \\
\hline 12 & $(1: 1)$ & $(3: 3)$ & 4.43 & 78.97 & 9.88 & 20 & 0.9819 & 165 & 0 & 0 & 690 & 8 \\
\hline
\end{tabular}

$\mathrm{EtOH}$, ethanol; HAc, acetic acid; $\mathrm{HPr}$, propionic acid; I-HBu, isobutyric acid; $\mathrm{NH}_{4}-\mathrm{N}$, ammonium nitrogen content; N-HBu, butyric acid; $\mathrm{R}^{2}$, Correlation coefficient; VFA, volatile fatty acid.

\subsection{Yield optimization with mineral supplementation}

As mentioned earlier, only four minerals are essential for hydrogen production by $C$. butyricum RAK25832. The optimal concentrations of these minerals were determined as follows: $\mathrm{MgCl}_{2} \cdot 6 \mathrm{H}_{2} \mathrm{O}$ $(0.1 \mathrm{~g} / \mathrm{l}), \mathrm{K}_{2} \mathrm{HPO}_{4} \cdot 3 \mathrm{H}_{2} \mathrm{O}(6.67 \mathrm{~g} / \mathrm{l}), \mathrm{NaHCO}_{3}(2.6 \mathrm{~g} / \mathrm{l})$, and $\mathrm{FeCl}_{2} \cdot 4 \mathrm{H}_{2} \mathrm{O}(0.002 \mathrm{~g} / \mathrm{l})$.

\subsubsection{Optimizing $\mathrm{FeCl}_{2} \cdot 4 \mathrm{H}_{2} \mathrm{O}$ concentration}

Iron is the most important nutrient for hydrogen gas production as it is utilized for the formation of hydrogenase and other enzymes (Lee et al., 2001; Oztekin et al., 2008). $\mathrm{FeCl}_{2} \cdot 4 \mathrm{H}_{2} \mathrm{O}$ was tested at concentrations of $0,0.001,0.002$, and $0.004 \mathrm{~g} / \mathrm{l}$. Eliminating $\mathrm{FeCl}_{2} \cdot 4 \mathrm{H}_{2} \mathrm{O}$ decreased $\mathrm{HY}$ by $55 \%$. Increasing the concentration above $0.002 \mathrm{~g} / \mathrm{l}$ had no effect, whereas a concentration of $0.002 \mathrm{~g} / \mathrm{l}$ had a yield $86 \mathrm{ml} \mathrm{H}_{2} / \mathrm{g} \mathrm{VS}$ and a rate $38 \mathrm{ml} \mathrm{H}_{2} / \mathrm{h}$. On the other hand, lag time was not greatly affected by $\mathrm{FeCl}_{2} \cdot 4 \mathrm{H}_{2} \mathrm{O}$ concentration (Fig. 2A), while VFA was unaffected by increases in $\mathrm{FeCl}_{2} \cdot 4 \mathrm{H}_{2} \mathrm{O}$ concentration beyond $0.002 \mathrm{~g} / \mathrm{l}$ (Fig. 3A). 


\subsubsection{Optimizing $\mathrm{NaHCO}_{3}$ concentration}

$\mathrm{NaHCO}_{3}$ concentrations in the range of $0-3.47 \mathrm{~g} / \mathrm{l}$ were tested (Fig. 2B). Complete elimination increased lag time to $21 \mathrm{~h}$ and decreased yield to $41 \%\left(51 \mathrm{ml} \mathrm{H}_{2} / \mathrm{g} \mathrm{VS}\right)$. The optimal concentration was $1.73 \mathrm{~g} / \mathrm{l}$, which yielded $98 \mathrm{ml} \mathrm{H}_{2} / \mathrm{g} \mathrm{VS}$, increased the rate to $39 \mathrm{ml} \mathrm{H}_{2} / \mathrm{h}$, and reduced lag time to 2 h. Further increases in the concentration decreased hydrogen production. VFA production increased with concentration up to $1.73 \mathrm{~g} / \mathrm{l}$, with a slight decrease observed at higher concentrations (Fig. 3B). $\mathrm{NaHCO}_{3}$ is commonly used as a buffer in the culture medium to neutralize acidic reaction by-products (Ai et al., 2014; Lee et al., 2004). $\mathrm{A} \mathrm{NaHCO}_{3}$ concentration of $0.124 \%$ (w/v) was previously reported as the optimal concentration for C. butyricum cultures (He et al., 2004).

\subsubsection{Optimizing $\mathrm{MgCl}_{2} \cdot 6 \mathrm{H}_{2} \mathrm{O}$ concentration}

The effect of $\mathrm{MgCl}_{2} \cdot 6 \mathrm{H}_{2} \mathrm{O}$ was examined at concentrations of $0,0.1,0.2$, and $0.4 \mathrm{~g} / \mathrm{l}$ (Fig. 2C). In the absence of $\mathrm{MgCl}_{2} \cdot 6 \mathrm{H}_{2} \mathrm{O}$, the yield decreased by $28 \%$, whereas concentrations above $0.1 \mathrm{~g} / \mathrm{l}$ did not increase yield beyond $87 \mathrm{ml} \mathrm{H}_{2} / \mathrm{g} \mathrm{VS}$ with a rate $37 \mathrm{ml} \mathrm{H}_{2} / \mathrm{h}$. VFA production caused the culture to become acidified (Fig. 3C). In additional, VFA was not affected by increasing $\mathrm{MgCl}_{2} \cdot 6 \mathrm{H}_{2} \mathrm{O}$ concentration. Microorganisms mainly require $\mathrm{Mg}^{2+}$ for ribosome activity, as a cell membrane and cell wall constituent, and as an enzyme cofactor. Thus, a decrease in $\mathrm{Mg}^{2+}$ concentration reduced cell growth and ultimately, hydrogen production (Lin \& Lay, 2005; Wang et al., 2007).

\subsubsection{Optimizing $\mathrm{K}_{2} \mathrm{HPO}_{4} \cdot 3 \mathrm{H}_{2} \mathrm{O}$ concentration}

The presence of $\mathrm{P}$ can improve microbial functions, including enzymatic activity and cell growth (Jo et al., 2008; Lin \& Lay, 2004). The effect of $\mathrm{K}_{2} \mathrm{HPO}_{4} \cdot 3 \mathrm{H}_{2} \mathrm{O}$ was examined at concentrations of $0,1.6$, 3.33, and $6.67 \mathrm{~g} / \mathrm{l}$ (Fig. 2D). Eliminating $\mathrm{K}_{2} \mathrm{HPO}_{4} \cdot 3 \mathrm{H}_{2} \mathrm{O}$ decreased $\mathrm{HY}$ by $25 \%$. The optimal

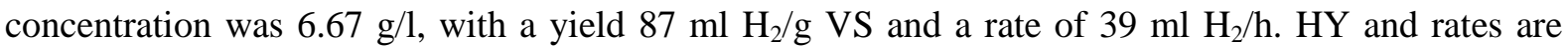
reported to be low in dark fermentations due to VFA accumulation (Liu \& Shen, 2004; Yokoi et al., 2001), which was observed at the end of the fermentation (Fig. 3D). VFA levels and lag time were unaffected by increasing concentrations of $\mathrm{K}_{2} \mathrm{HPO}_{4} \cdot 3 \mathrm{H}_{2} \mathrm{O}$.

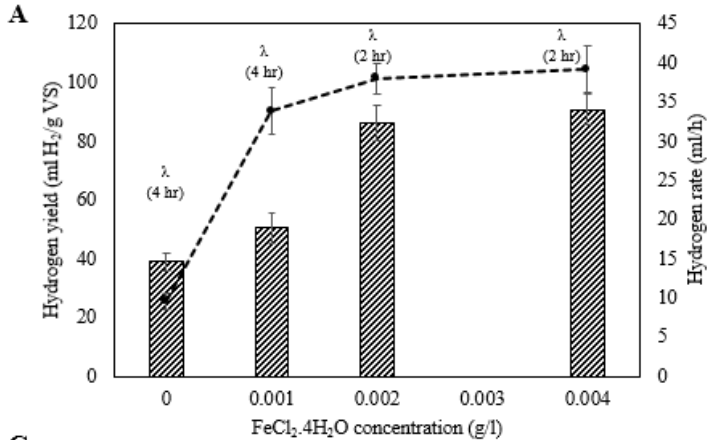

C

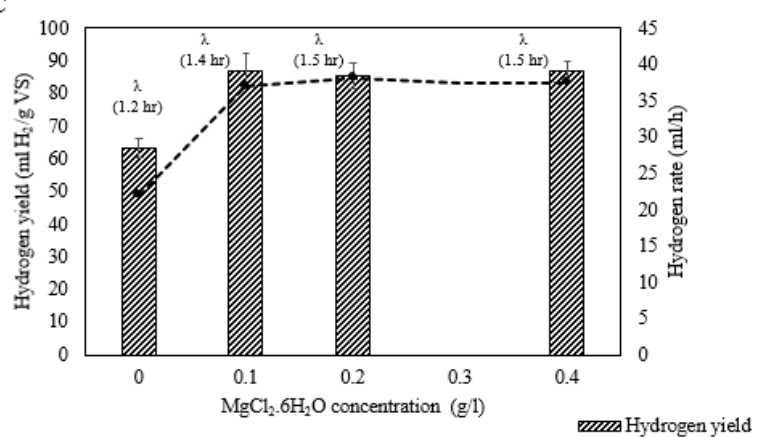

B

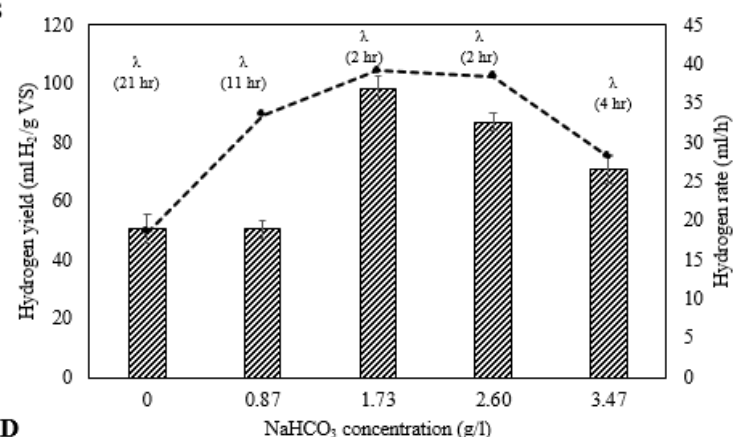

D

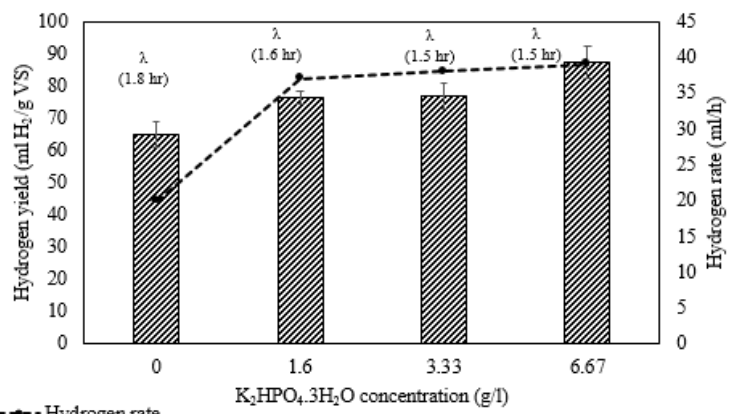

Figure 2. Effect of different concentrations of (A) $\mathrm{FeCl}_{2} \cdot 4 \mathrm{H}_{2} \mathrm{O}$, (B) $\mathrm{NaHCO}_{3}$, (C) $\mathrm{MgCl}_{2} \cdot 6 \mathrm{H}_{2} \mathrm{O}$, and (D) $\mathrm{K}_{2} \mathrm{HPO}_{4} \cdot 3 \mathrm{H}_{2} \mathrm{O}$ and a C. fusca and U. lactuca biomass ratio of $4: 1$ on $\mathrm{HY}$ and hydrogen production rate by $\mathrm{C}$. butyricum RAK25832 
Enhancement of Hydrogen Production by Combining a Blend Ratio for Two Types of Algal Waste Biomass and Reducing Casamino Acids Supplementation By Clostridium butyricum RAK25832
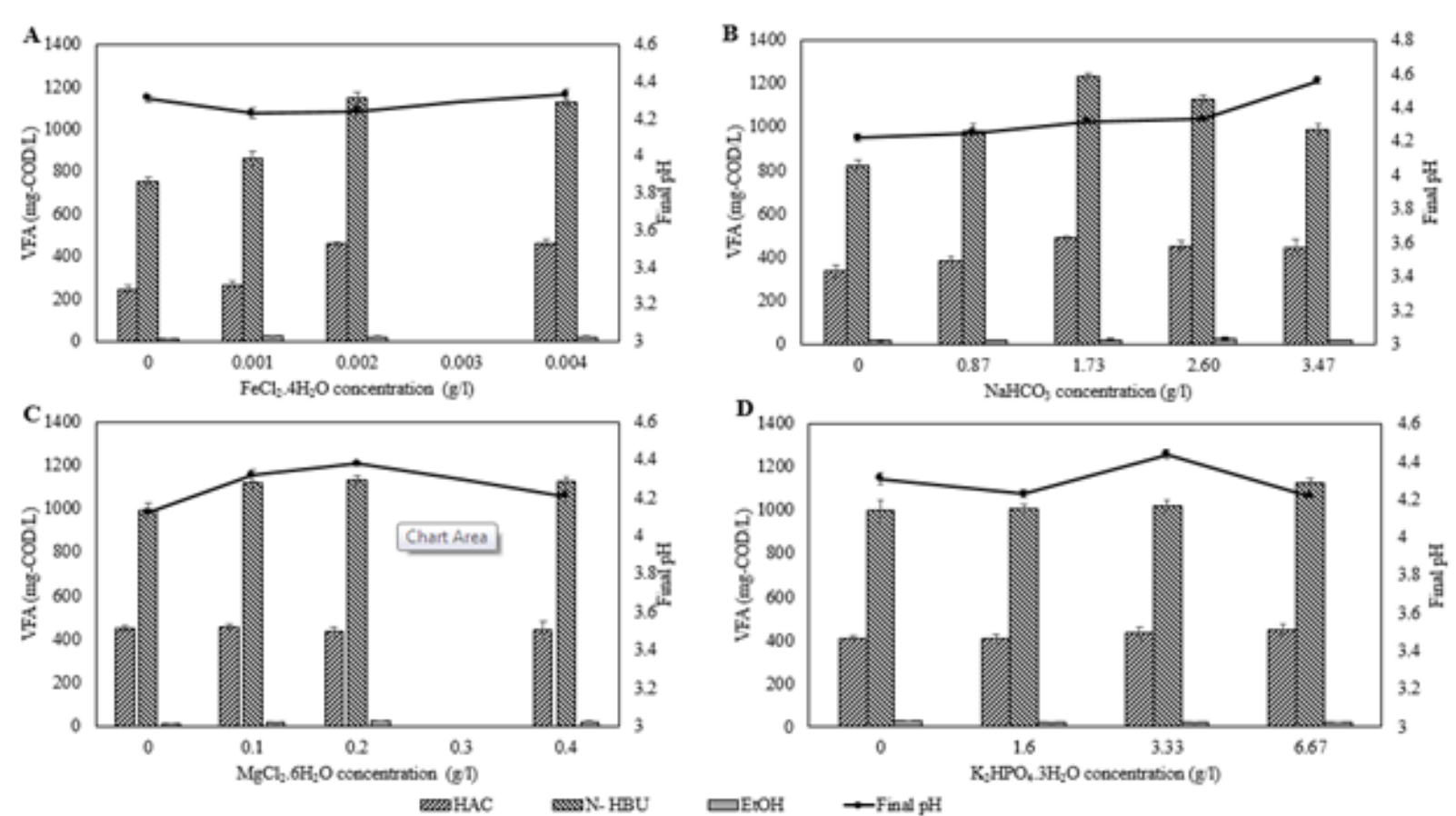

Figure 3. VFA produced in the presence of different concentrations of (A) $\mathrm{FeCl}_{2} \cdot 4 \mathrm{H}_{2} \mathrm{O}$, (B) $\mathrm{NaHCO}_{3}$, (C) $\mathrm{MgCl}_{2} \cdot 6 \mathrm{H}_{2} \mathrm{O}$, and $(\mathrm{D}) \mathrm{K}_{2} \mathrm{HPO}_{4} \cdot 3 \mathrm{H}_{2} \mathrm{O}$ at a $\mathrm{C}$. fusca and $\mathrm{U}$. lactuca biomass ratio of $4: 1$, relative to final $\mathrm{pH}$

\subsection{Effect of combining CAAs with algal biomass on $H Y$}

\subsubsection{CAAs combined with a blend of $C$. fusca and $U$. lactuca}

The effect of combining CAAs with algal biomass (group 6, C. fusca : U. lactuca ratio of $4: 1$ ) as a nitrogen source were examined on hydrogen production by C. butyricum RAK25832. Cultures were also supplemented with optimal concentrations of $\mathrm{MgCl}_{2} \cdot 6 \mathrm{H}_{2} \mathrm{O}(0.1 \mathrm{~g} / \mathrm{l}), \mathrm{K}_{2} \mathrm{HPO}_{4} \cdot 3 \mathrm{H}_{2} \mathrm{O}(6.67 \mathrm{~g} / \mathrm{l})$, $\mathrm{NaHCO}_{3}(1.73 \mathrm{~g} / \mathrm{l})$, and $\mathrm{FeCl}_{2} \cdot 4 \mathrm{H}_{2} \mathrm{O}(0.002 \mathrm{~g} / \mathrm{l})$ (Fig. 4). CAAs concentrations were 0, 1.67, 3.33, $6.67,13.33$, and $26.67 \mathrm{~g} / \mathrm{l}$. It was found that CAAs had a significant effect on hydrogen production: a concentration of $3.33 \mathrm{~g} / \mathrm{l}$ increased the yield from 107 to $117 \mathrm{ml} \mathrm{H}_{2} / \mathrm{g}$ VS, possibly by providing HPB with the remaining amino acids required for fermentation. Acetic acid and butyric acid were the main VFAs produced by fermentation (Fig. 5), resulting in acidification of the culture.

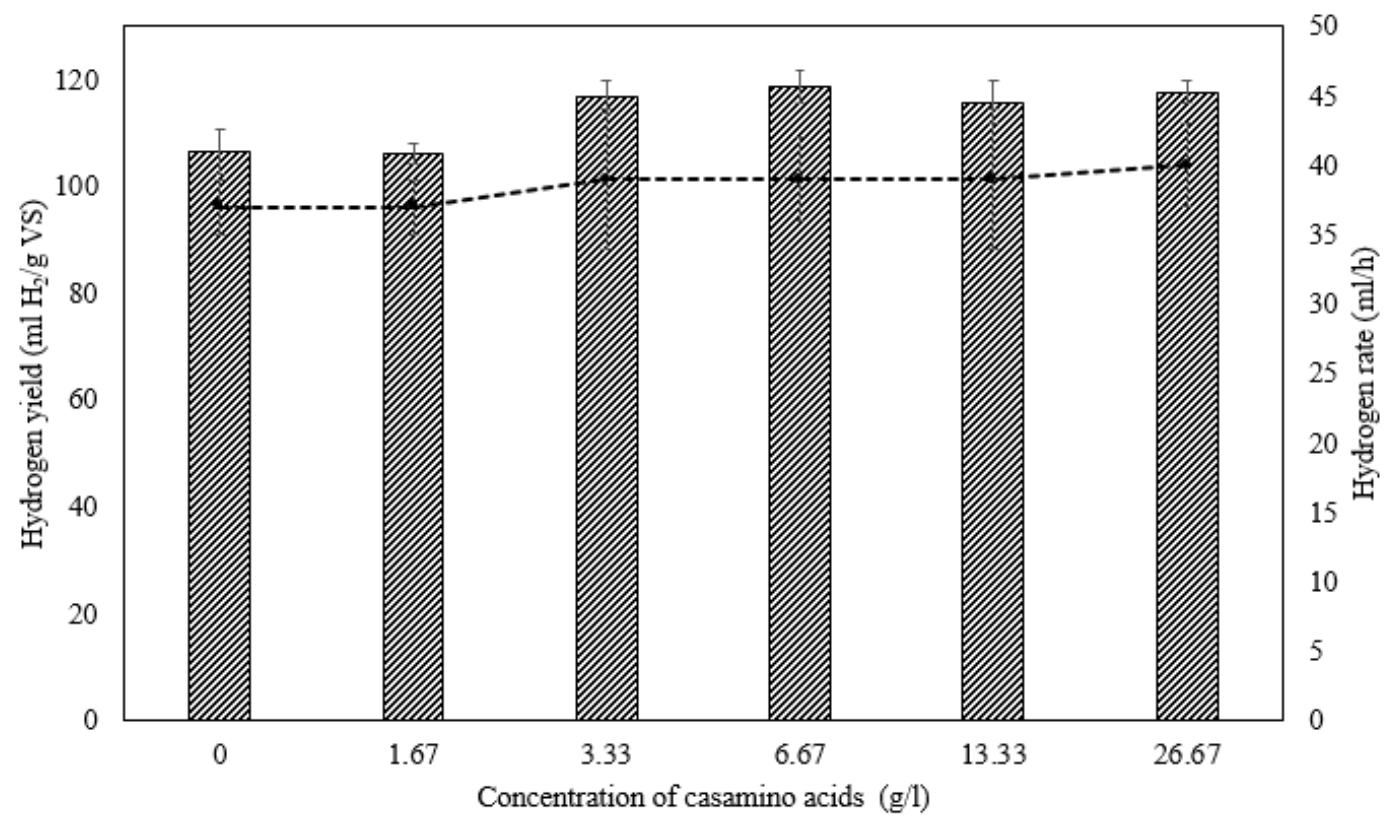

mym Hydrogen yield

---Hydrogen rate

Figure 4. Effect of different concentrations of CAAs combined with C. fusca and U. lactuca biomass at a ratio of $4: 1$ on $H Y$ and hydrogen production rate by C. butyricum RAK25832 


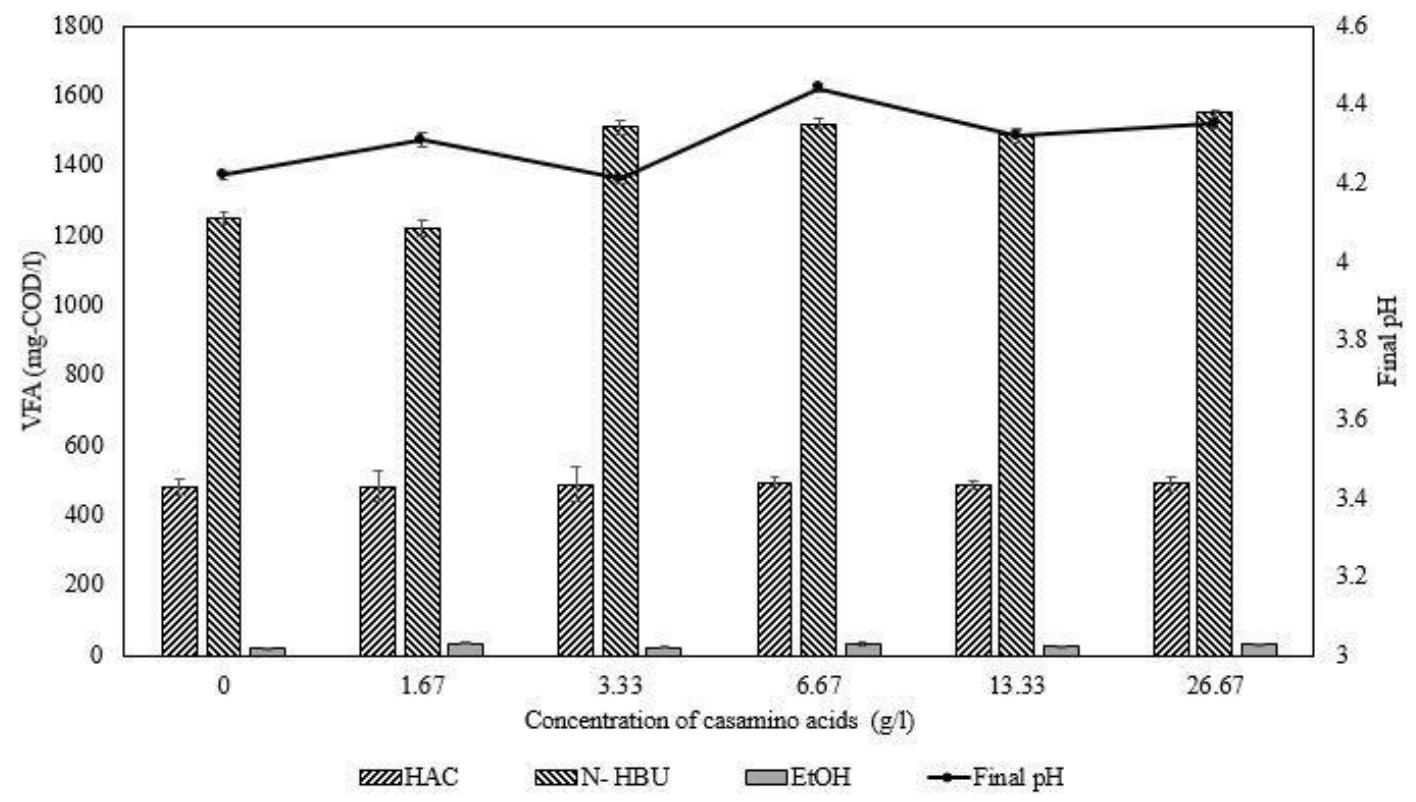

Figure 5. VFAs associated with different CAAs concentrations combined C. fusca and U. lactuca biomass at a ratio of $4: 1$ relative to final $\mathrm{pH}$

\subsubsection{CAAs combined with a single type of algal biomass}

A maximum $\mathrm{HY}$ of $111 \mathrm{ml} \mathrm{H}_{2} / \mathrm{g}$ VS-representing a $50 \%$ increase-was achieved with a CAAs concentration of $13.33 \mathrm{~g} / \mathrm{l}$ in the presence of $C$. fusca (Fig. 6A). It was speculated that a similarly high yield could be achieved by including waste algae biomass and thereby decreasing the amount of CAAs required. A CAAs concentration of $6.67 \mathrm{~g} / \mathrm{l}$ was required to obtain a maximum yield of $94 \mathrm{ml}$ $\mathrm{H}_{2} / \mathrm{g}$ VS in the presence of $U$. lactuca (Fig. 6B), which was higher than the concentration required when using a mixture of the two types of algal biomass.

The fact that a lower amount of CAAs was required in the presence of $U$. lactuca as compared with that in the presence of $C$. fusca may be related to the higher free amino acids concentration in the former (Table 3). The amino acid requirements of HPB were met by using the algal blend biomass, although CAAs compensated for the low levels of some amino acids. Thus, blending the two types of algal waste biomass could reduce the amount of CAAs required for fermentation and thereby lower the cost of hydrogen production by dark fermentation.

Table 3. Analysis of amino acid composition in C. fusca and U. lactuca

\begin{tabular}{|c|c|c|}
\hline & C. fusca $\mathbf{( m g / g )}$ & U. lactuca $(\mathbf{m g} / \mathbf{g})$ \\
\hline Amino acid & 0.196 & 0.199 \\
\hline Asp & 0.490 & 0.199 \\
\hline Thr & 0.294 & 0.299 \\
\hline Ser & 0.294 & 0.249 \\
\hline Asn & 0.735 & 1.643 \\
\hline Glu & 0.147 & 1.444 \\
\hline Gln & 0.245 & 0.598 \\
\hline Gly & 2.645 & 0.747 \\
\hline Ala & 0.049 & 0.149 \\
\hline Cit & 0.294 & 0.498 \\
\hline Val & 0.147 & 0.349 \\
\hline Ile & 0.245 & 0.349 \\
\hline Leu & 0.147 & 0.249 \\
\hline Tyr & 0.196 & 0.199 \\
\hline Phe & 0.098 & 0.149 \\
\hline His & 1.029 & 0.598 \\
\hline Lys & 0.441 & 1.145 \\
\hline Arg & 0.931 & 0.647 \\
\hline Pro & & \\
\hline & & \\
\hline
\end{tabular}



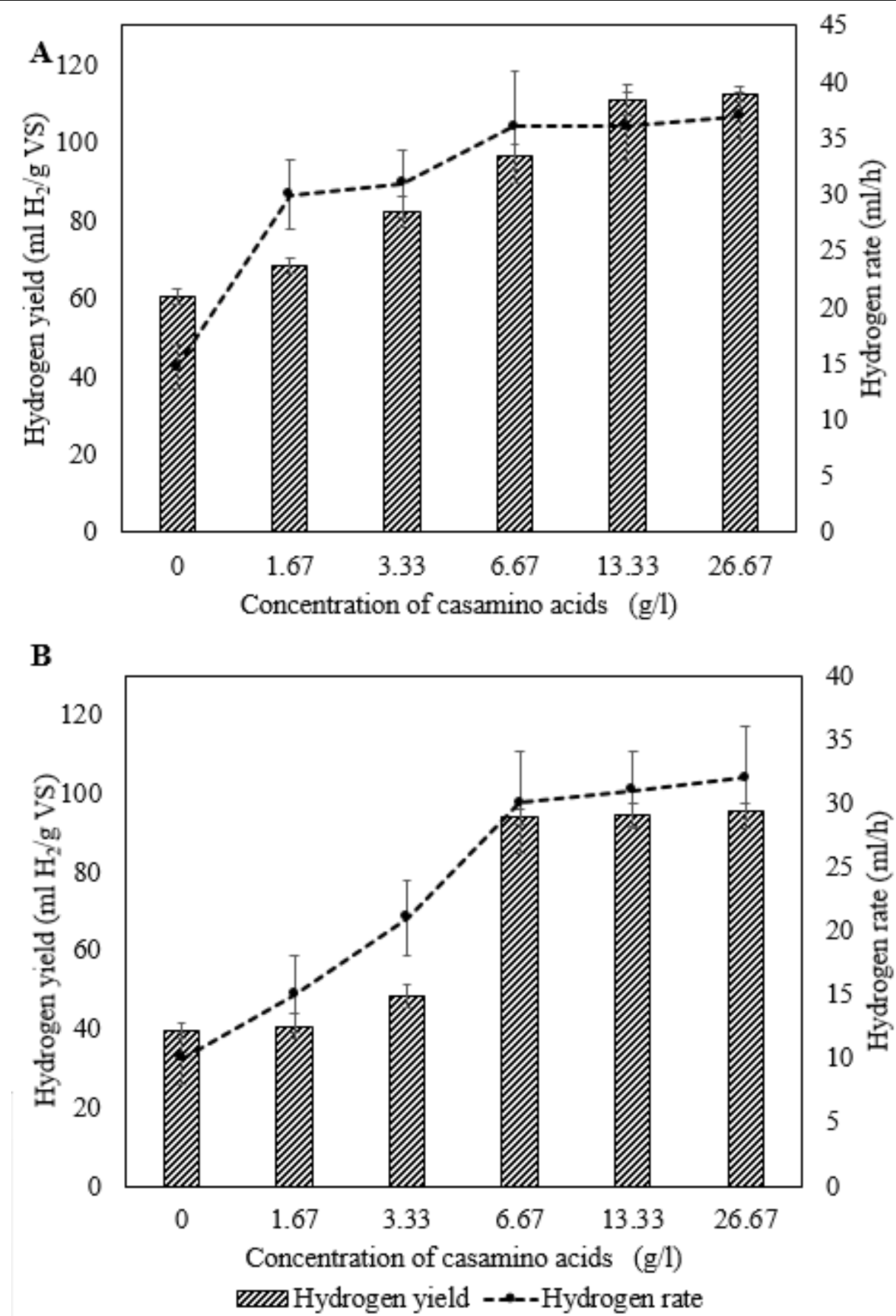

Figure 6. Effect of different concentrations of CAAs combined with A) C. fusca and B) U. lactuca on HY and hydrogen production rate by $C$. butyricum RAK25832

\section{CONCLUSiONS}

The present study investigated the possibility of reducing the requirement for CAAs - an effective but costly nitrogen source - in biohydrogen fermentation by C. butyricum RAK25832-mediated dark fermentation via the introduction of an algal waste biomass blend. A C. fusca: U. lactuca ratio of $4: 1$ reduced the amount of CAAs required to $3.33 \mathrm{~g} / \mathrm{l}$. The deficiency in metal ions in algal waste was partly mitigated by mineral supplementation. Based on these results, the use of more than one nitrogen source to meet the nitrogen requirements of dark fermentation by C. butyricum RAK25832 is recommended for maximal $\mathrm{HY}$.

\section{REFERENCES}

Ai, B., Li, J., Chi, X., Meng, J., Jha, A.K., Liu, C., Shi, E. 2014. Effect of pH and buffer on butyric acid production and microbial community characteristics in bioconversion of rice straw with undefined mixed culture. Biotechnol. Bioprocess Eng. 19, 676-686. 
Enhancement of Hydrogen Production by Combining a Blend Ratio for Two Types of Algal Waste Biomass and Reducing Casamino Acids Supplementation By Clostridium butyricum RAK25832

Allen, E., Browne, J., Hynes, S., Murphy, J. 2013a. The potential of algae blooms to produce renewable gaseous fuel. Waste Manag. 33, 2425-2433.

Allen, E., Browne, J.D., Murphy, J.D. 2013b. Evaluation of the biomethane yield from anaerobic co-digestion of nitrogenous substrates. Environ. Technol. 34, 2059-2068.

Aly, S.S., Imai, T., Hassouna, M.S., Nguyen, D.-M.K., Higuchi, T., Kanno, A., Yamamoto, K., Akada, R., Sekine, M. 2017. Identification of factors that accelerate hydrogen production by Clostridium butyricum RAK25832 using casamino acids as a nitrogen source. Int. J. Hydrog. Energy. doi: 10.1016/j.ijhydene.2017.08.171

APHA, AWWA, WEF. 2005. Standard Methods for the Examination of Water and Wastewater, 21 th ed. American Public Health Association, Washington, DC.

Azwar, M., Hussain, M., Abdul-Wahab, A. 2014. Development of biohydrogen production by photobiological, fermentation and electrochemical processes: A review. Renew. Sust. Energy Rev. 31, 158-173.

Balat, H. 2010. Prospects of biofuels for a sustainable energy future: a critical assessment. Energy Educ. Sci. Tech. A. 24, 85-111.

Berges, J.A., Fisher, A.E., Harrison, P.J. 1993. A comparison of Lowry, Bradford and Smith protein assays using different protein standards and protein isolated from the marine diatom Thalassiosira pseudonana. Mar. Biol.115, 187-193.

Bligh, E.G., Dyer, W.J. 1959. A rapid method of total lipid extraction and purification. Can. J. Biochem. Physiol. 37, 911-917.

Brennan, L., Owende, P. 2010. Biofuels from microalgae - a review of technologies for production, processing, and extractions of biofuels and co-products. Renew. Sust. Energy Rev. 14, 557-577.

Cheng, C.-L., Lo, Y.-C., Lee, K.-S., Lee, D.-J., Lin, C.-Y., Chang, J.-S. 2011. Biohydrogen production from lignocellulosic feedstock. Bioresour. Technol. 102, 8514-8523.

Diaz, R.J. 2001. Overview of hypoxia around the world. J. Environ. Qual. 30, 275-281.

Dismukes, G.C., Carrieri, D., Bennette, N., Ananyev, G.M., Posewitz, M.C. 2008. Aquatic phototrophs: efficient alternatives to land-based crops for biofuels. Curr. Opin. Biotechnol. 19, 235-240.

Ehimen, E., Sun, Z., Carrington, C., Birch, E., Eaton-Rye, J. 2011. Anaerobic digestion of microalgae residues resulting from the biodiesel production process. Appl. Energy. 88, 3454-3463.

Fargione, J., Hill, J., Tilman, D., Polasky, S., Hawthorne, P. 2008. Land clearing and the biofuel carbon debt. Science. 319, 1235-1238.

Hahn-Hägerdal, B., Galbe, M., Gorwa-Grauslund, M.-F., Lidén, G., Zacchi, G. 2006. Bio-ethanol-the fuel of tomorrow from the residues of today. Trends Biotechnol. 24, 549-556.

Hauxwell, J., Cebrián, J., Furlong, C., Valiela, I. 2001. Macroalgal canopies contribute to eelgrass (Zostera marina) decline in temperate estuarine ecosystems. Ecology. 82, 1007-1022.

He, G., Kong, Q., Ding, L. 2004. Response surface methodology for optimizing the fermentation medium of Clostridium butyricum. Lett. Appl. Microbiol. 39, 363-368.

Jo, J.H., Lee, D.S., Park, D., Choe, W.-S., Park, J.M. 2008. Optimization of key process variables for enhanced hydrogen production by Enterobacter aerogenes using statistical methods. Bioresour. Technol. 99, 20612066.

Jones, C.S., Mayfield, S.P. 2012. Algae biofuels: versatility for the future of bioenergy. Curr. Opin. Biotechnol. 23, 346-351.

Kan, A. 2009. General characteristics of waste management: A review. Energy Educ. Sci. Tech. A. 23, 55-69.

Lay, J.-J., Li, Y.-Y., Noike, T. 1997. Influences of $\mathrm{pH}$ and moisture content on the methane production in highsolids sludge digestion. Water Res. 31, 1518-1524.

Lee, K.S., Wu, J.F., Lo, Y.S., Lo, Y.C., Lin, P.J., Chang, J.S. 2004. Anaerobic hydrogen production with an efficient carrier-induced granular sludge bed bioreactor. Biotechnol. Bioeng. 87, 648-657.

Lee, Y.J., Miyahara, T., Noike, T. 2001. Effect of iron concentration on hydrogen fermentation. Bioresour. Technol. 80, 227-231.

Lev, M. 1977. Casamino acids enhance growth of Bacteroides melaninogenicus. J. Bacteriol. 129, 562-563.

Lin, C., Lay, C. 2004. Carbon/nitrogen-ratio effect on fermentative hydrogen production by mixed microflora. Int. J. Hydrog. Energy. 29, 41-45.

Lin, C., Lay, C. 2005. A nutrient formulation for fermentative hydrogen production using anaerobic sewage sludge microflora. Int. J. Hydrog. Energy. 30, 285-292.

Lindsay, J., Murrell, W. 1983. A comparison of UV induced DNA photoproducts from isolated and non-isolated developing bacterial forespores. Biochem. Biophys. Res. Commun. 113, 618-625. 
Enhancement of Hydrogen Production by Combining a Blend Ratio for Two Types of Algal Waste Biomass and Reducing Casamino Acids Supplementation By Clostridium butyricum RAK25832

Liu, B.-F., Ren, N.-Q., Ding, J., Xie, G.-J., Guo, W.-Q. 2009. The effect of Ni 2+, Fe 2+ and Mg 2+ concentration on photo-hydrogen production by Rhodopseudomonas faecalis RLD-53. Int. J. Hydrog. Energy. 34, 721-726.

Liu, G., Shen, J. 2004. Effects of culture and medium conditions on hydrogen production from starch using anaerobic bacteria. J. Biosci. Bioeng. 98, 251-256.

Logan, B.E., Oh, S.-E., Kim, I.S., Van Ginkel, S. 2002. Biological hydrogen production measured in batch anaerobic respirometers. Env. Sci. Technol. 36, 2530-2535.

Murphy, J.D., Drosg, B., Allen, E., Jerney, J., Xia, A., Herrmann, C. 2015. A perspective on algal biogas. IEA Bioenergy, 1-38.

Nolan, R.A. 1971. Amino acids and growth factors in vitamin-free casamino acids. Mycologia. 63, 1231-1234.

Owen, W., Stuckey, D., Healy, J., Young, L., McCarty, P. 1979. Bioassay for monitoring biochemical methane potential and anaerobic toxicity. Water Res. 13, 485-492.

Oztekin, R., Kapdan, I.K., Kargi, F., Argun, H. 2008. Optimization of media composition for hydrogen gas production from hydrolyzed wheat starch by dark fermentation. Int. J. Hydrog. Energy. 33, 4083-4090.

Pan, X., Wu, T., Zhang, L., Song, Z., Tang, H., Zhao, Z. 2008. In vitro evaluation on adherence and antimicrobial properties of a candidate probiotic Clostridium butyricum CB2 for farmed fish. J. Appl. Microbiol. 105, 1623-1629.

Park, J.-I., Lee, J., Sim, S.J., Lee, J.-H. 2009. Production of hydrogen from marine macro-algae biomass using anaerobic sewage sludge microflora. Biotechnol Bioprocess Eng. 14, 307.

Sialve, B., Bernet, N., Bernard, O. 2009. Anaerobic digestion of microalgae as a necessary step to make microalgal biodiesel sustainable. Biotechnol. Adv. 27, 409-416.

Sugimoto, K., Hiraoka, K., Ohta, S., Niimura, Y., Terawaki, T., Okada, M. 2007. Effects of ulvoid (Ulva spp.) accumulation on the structure and function of eelgrass (Zostera marina L.) bed. Marine Poll. Bull. 54, $1582-1585$.

Wang, J., Wan, W. 2009. Factors influencing fermentative hydrogen production: a review. Int. J. Hydrog. Energy. 34, 799-811.

Wang, X.J., Ren, N.Q., Xiang, W.S., Guo, W.Q. 2007. Influence of gaseous end-products inhibition and nutrient limitations on the growth and hydrogen production by hydrogen-producing fermentative bacterial B49. Int. J. Hydrog. Energy. 32, 748-754.

Wei, N., Quarterman, J., Jin, Y.-S. 2013. Marine macroalgae: an untapped resource for producing fuels and chemicals. Trends Biotechnol. 31, 70-77.

Wilce, R., Schneider, C., Quinlan, A., Bosch, K.V. 1982. The life history and morphology of free-living Pilayella littoralis (L.) Kjellm. (Ectocarpaceae, Ectocarpales) in Nahant Bay, Massachusetts. Phycologia. 21, 336-354.

Xia, A., Cheng, J., Song, W., Su, H., Ding, L., Lin, R., Lu, H., Liu, J., Zhou, J., Cen, K. 2015. Fermentative hydrogen production using algal biomass as feedstock. Renew. Sust. Energy Rev. 51, 209-230.

Xia, A., Jacob, A., Tabassum, M.R., Herrmann, C., Murphy, J.D. 2016. Production of hydrogen, ethanol and volatile fatty acids through co-fermentation of macro-and micro-algae. Bioresour. Technol. 205, 118-125.

Yang, Z., Guo, R., Xu, X., Fan, X., Li, X. 2010. Enhanced hydrogen production from lipid-extracted microalgal biomass residues through pretreatment. Int. J. Hydrog. Energy. 35, 9618-9623.

Yokoi, H., Saitsu, A., Uchida, H., Hirose, J., Hayashi, S., Takasaki, Y. 2001. Microbial hydrogen production from sweet potato starch residue. J. Biosci. Bioeng. 91, 58-63.

Citation: S. S. Aly et al., " Enhancement of Hydrogen Production by Combining a Blend Ratio for Two Types of Algal Waste Biomass and Reducing Casamino Acids Supplementation By Clostridium butyricum RAK25832 ", International Journal of Research in Environmental Science, vol. 4, no. 1, p. 9-19, 2018. http://dx.doi.org/ 10.20431/2454-9444.0401002

Copyright: (C) 2018 Authors. This is an open-access article distributed under the terms of the Creative Commons Attribution License, which permits unrestricted use, distribution, and reproduction in any medium, provided the original author and source are credited. 